
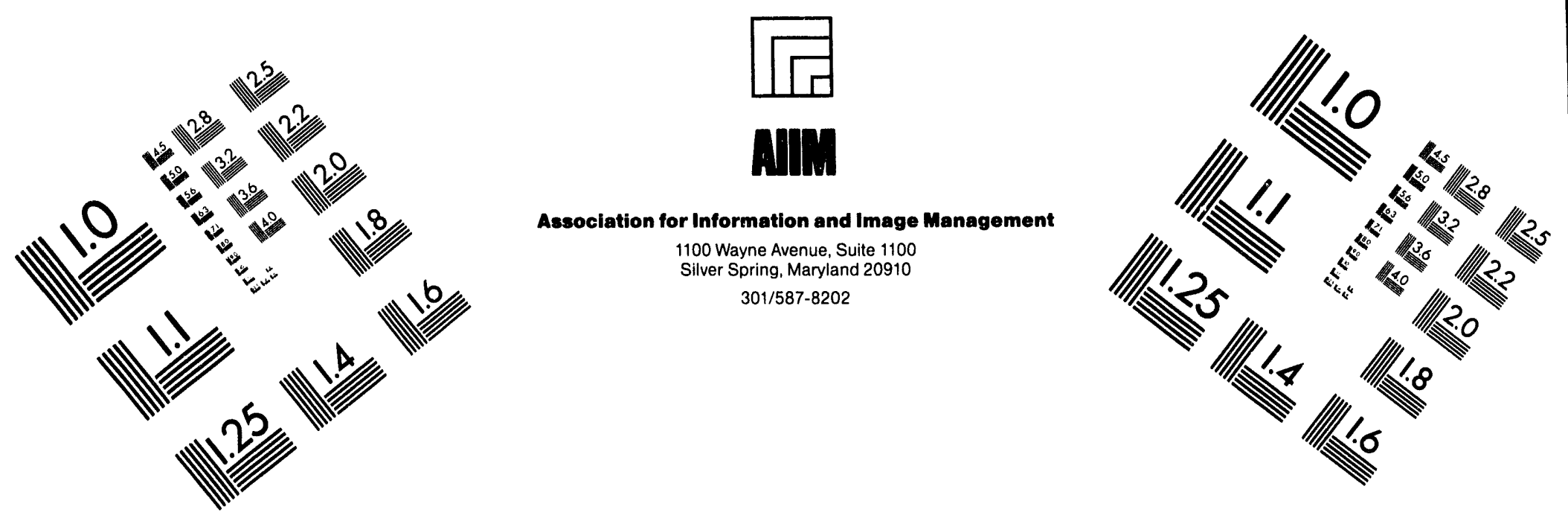

\title{
Centimeter
}

إس

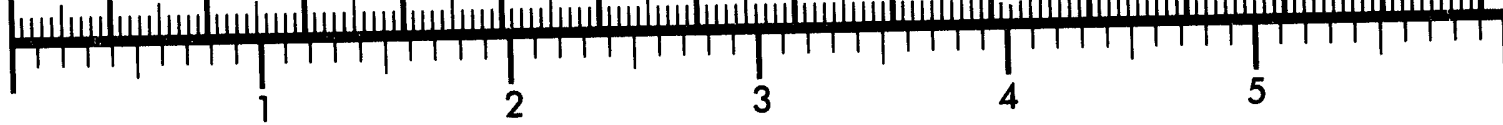
Inches

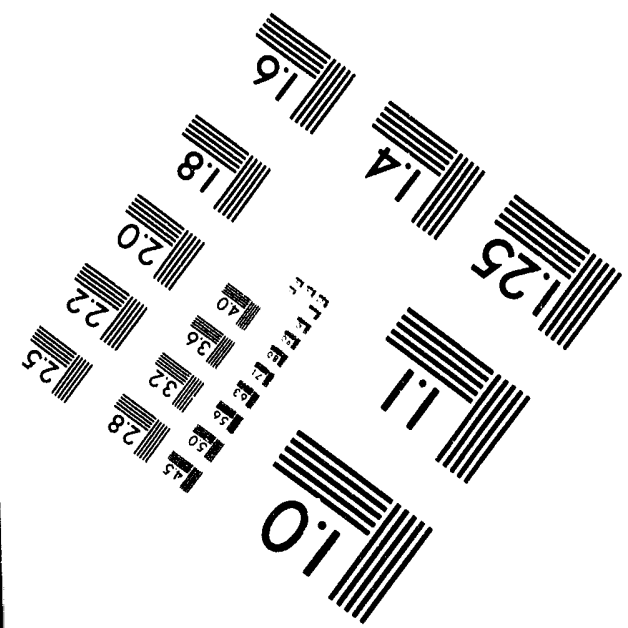

MANUFACTURED TO AIIM STANDARDS

BY APPLIED IMAGE, INC.

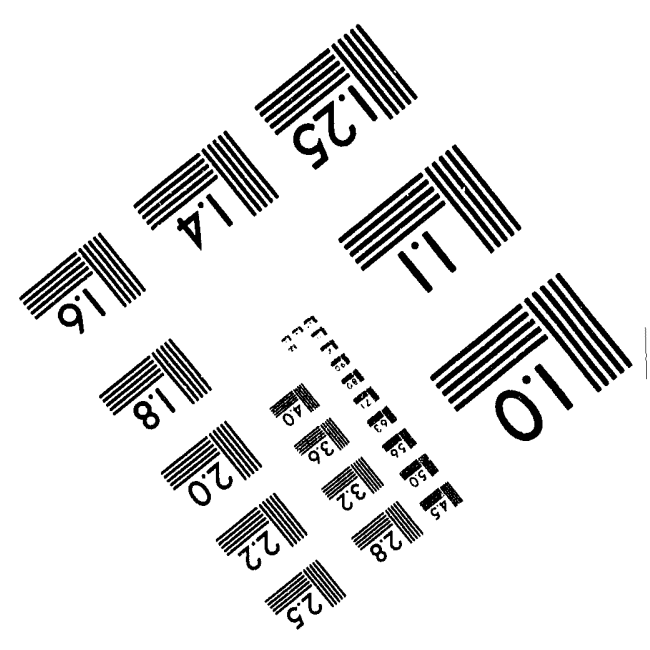



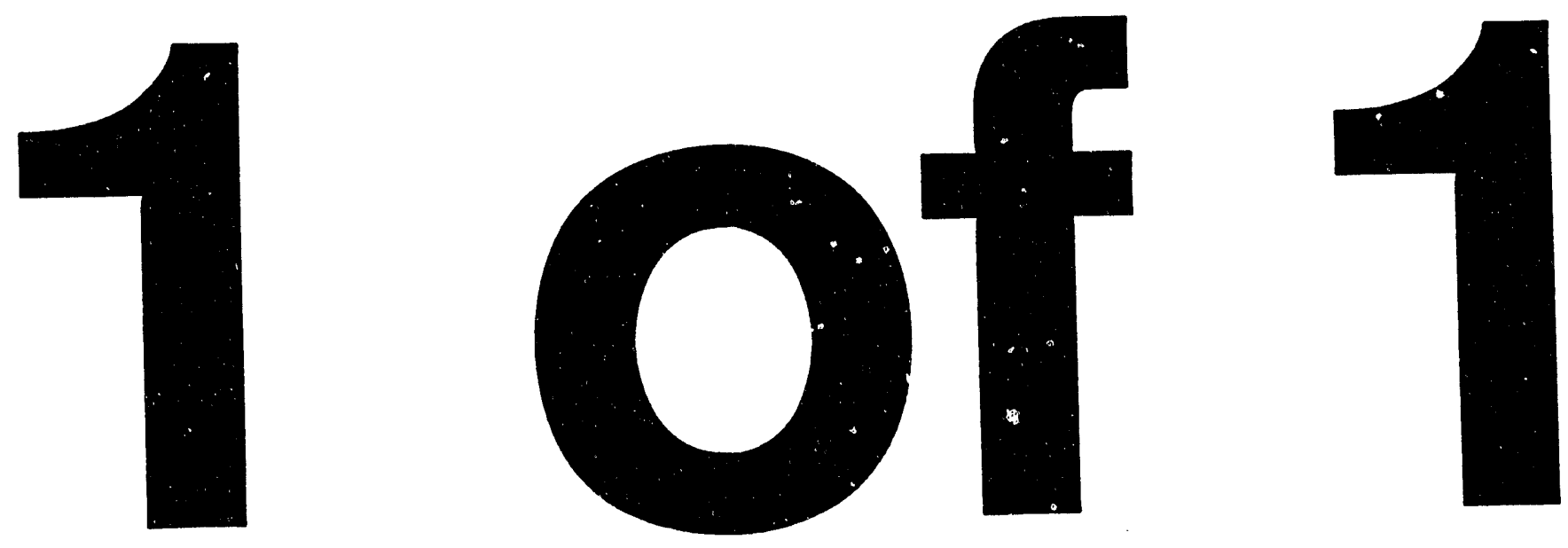


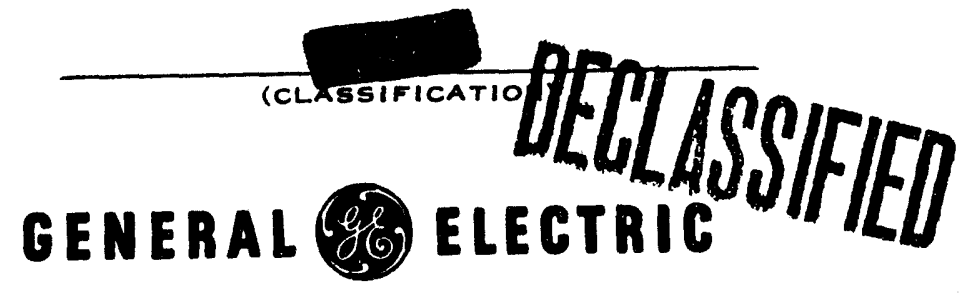

HANFORD ATOMIC PRODUCTS OPERATION - RICHLAND, WASHINGTON

\begin{tabular}{l} 
DOCUMENT NO. \\
HW-74104 \\
DERIES AND COPY NO. \\
OCtOber 19, 1962 \\
\hline
\end{tabular}

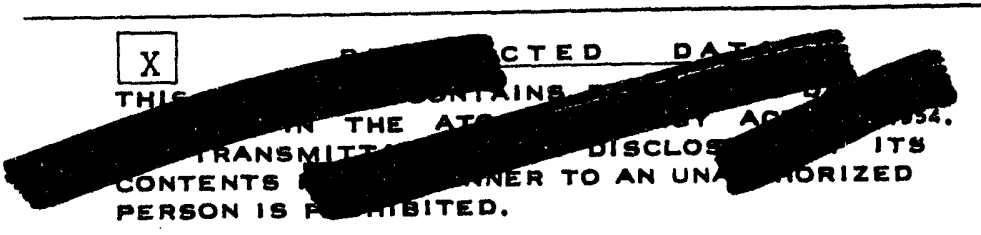

OTHER OFFICIAL CLASBIFIED INFORMATION

THIS MATERIAL CONTAINS INFORMATION AFFECTING THE NATIONAL DEFENSE OF THE UNITED STATES WITHIN THE MEANING OF THE ESPIONAGE LAWS. TITLE 18, U. S. C., SECS. 793 AND 794, THE TRANSMISSION OR REVELATION OF WHICH IN ANY MANNER TO AN UNAUTHORIZED PERSON IS PROHIBITED BY LAW.

\section{TECHNICAI CRITERIA AND BASES FOR A ZIRCONIUM-TUBED K REACTOR}

THIS DOCUMENT MUST MP TATTENDED OR My-

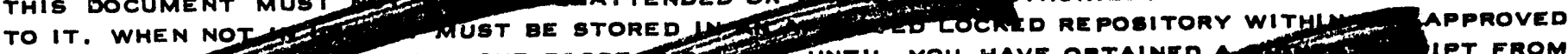

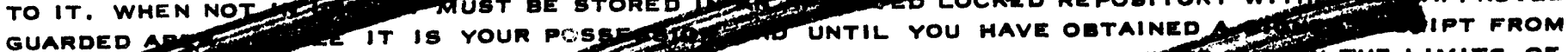

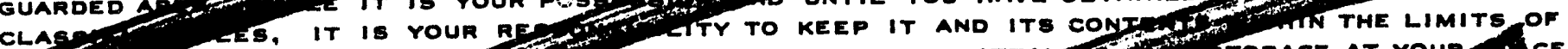

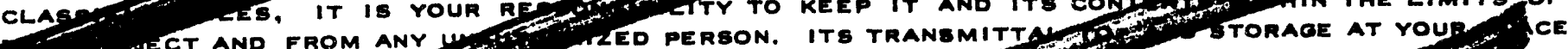
ISET AND FROM ANY IS NOT TO BE DUPLICATEOP OBTAIN THEM FROM TO SIGN IN THE BPACL MUVIDED BELOW.

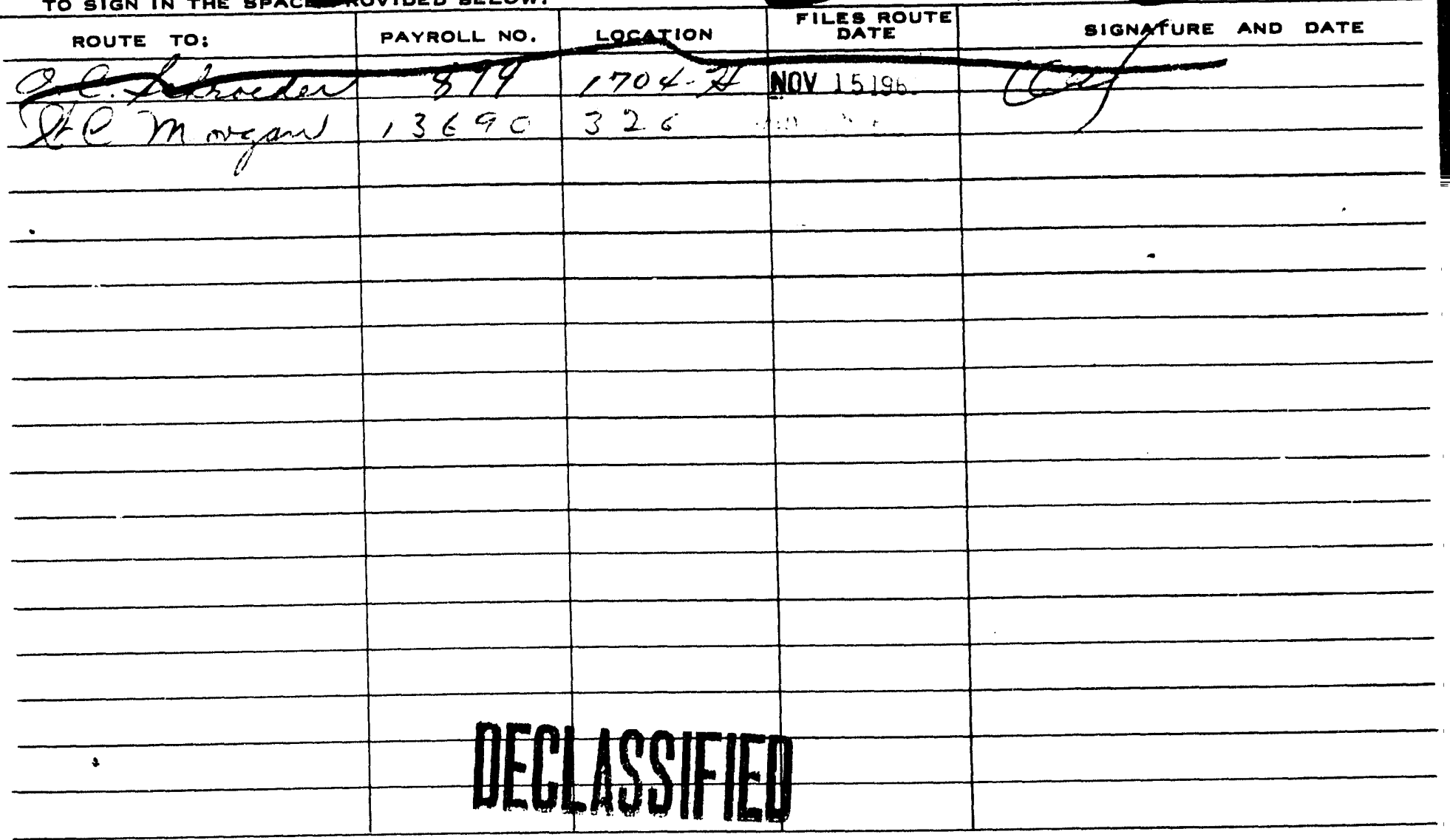

54-3000-340 (3-57) AEC-GE MICHLAND. WASH 


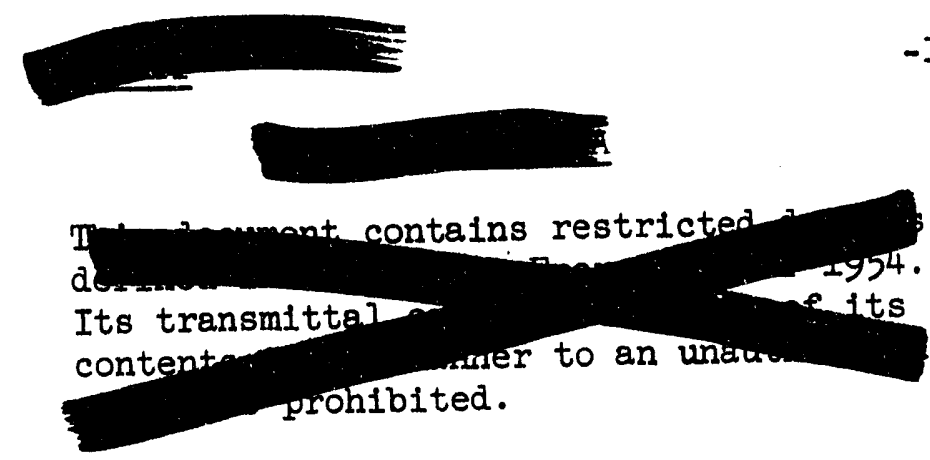

This document consists of $\frac{22}{62}$ pages. No. 47 of $\underline{63}$ copies. This dogument classified by TECHNICAL CRITERIA AND BASES FOR A ZIRCONIUM-TUBED K REACTOR

Edited by

D. H. Curtiss

Reactor Engineering Unit

Process and Reactor Development Subsection

Research and Engineering Section

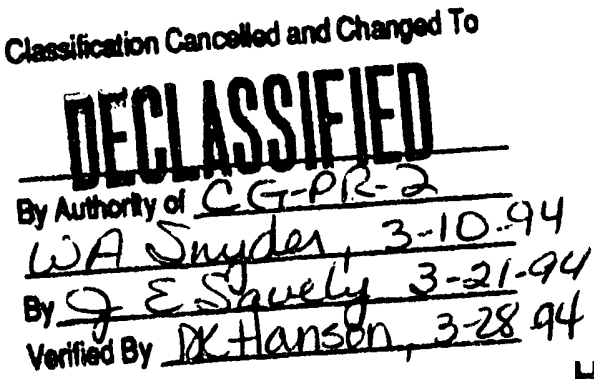

\title{
HANFORD ATOMIC PRODUCTS OPERATION RICHLAND. WASHINGTON
}

\begin{abstract}
NOTICE
This report was prepared for use within General Electric Company in the course of work under Atomic Energy Commission Contract AT(45-1)-1350, and any views or opinions expressed in the report are those of the author only. This report is subject to revision upon collection of additional data.
\end{abstract}

\section{LEGAL NOTICE}

This report was prepared as an account of Government sponsored work. Neither the United States, nor the Commission, nor any person acting on behalf of the Commission:

A. Makes any warranty or representation, expressed or implied, with respect to the accuracy, completeness, or usefulness of the information contained in this report, or that the use of any information, apparatus, method, or process disclosed in this report may not infringe privately owned rights; or

B. Assumes ary liabilities with respect to the use of, or for damages resulting from the use of any information, appuratus, method, or process disclosed in this report.

As used in the above, "person acting on behalf of the Commission" includes any employee or contractor of the Commission, or employee of such contractor, to the extent that such employee or contractor of the Commission, or employee of such contractor prepares, disseminates, or provides access to, any information pursuant to his employment or contract with the Commission, or his employment with such contractor.
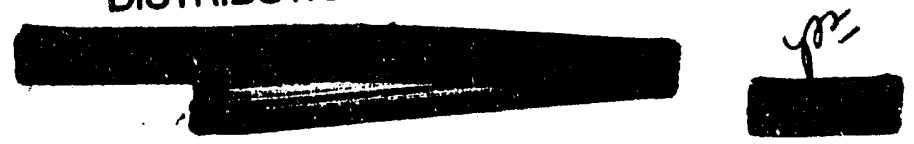


\section{DEELLSSIFIED}

Distribution

1. ER Astley -

2. RS Bell

3. CE Bowers

4. JH Brown

5. P. A. Carlson

6. RD Carter

7. RA Chitwood

8. MA Clinton

9. RG Clough

10. DI Condotta

11. RF Corlett

12. DH Curtiss

13. JA Dear

14. ML Faught

15. GC Fullmer

16. RG Geier

17. SM Graves

18. $\mathrm{OH}$ Greager

19. $A B$ Greninger

20. LL Grumme

21. RS Hammond

22. AK Hardin

23. HW Heacock

24. CM Heeb

25. AW Hervin

26. KI Hladek

27. DA Hoover

28. DI Hovorka

29. PC Jerman
30. RT Jessen

31. SS Jones

32. JE Kaveckis

33. LM Keene

34. IW Lang

35. IC Lessor

36. CG Lewis

37. PC McCarthy

38. JC McKay

39. PF Mercier

40. R Nilson

41. GF Owsley

42. RW Reid

43. DL Renberger

44. GJ Rogers

45. A Russell

46. MH Schack

47. OC Schroeder

48. W Seeburger

49. SH Small

50. HG Spencer

51. FW Van Wormer

52. FF Vlacil

53. GE Wade

54. EA Wegener

55. EE Weyerts

56. Records Center

57. 300 Files

58-63. Extra 
1.0 INTRODUCTION

\section{3.}

The criteria contained in this report have been established to provide the technical bases for the design modifications involved in the K-Reactor tube replacement. The ultimate intent of these criteria is to provide the basic technical data and concepts to assure: 1) technical feasibility and operability of the reactor system as modified; 2) operation of the reactor and its services to minimize nuclear and radiation hazards; and 3) appropriate lifetime of the reactor and its service facilities as modified. The criteria are appropriately broad and may not contain all the data necessary to accomplish detall design. The information contained herein shall serve as a basis for evaluation and approval of all portions of the modification relating to the process as indicated in the above three points.

For purposes of these criteria, the following ground rules apply:

1. The reactor modification involves the retubing of each $\mathrm{K}$ Reactor using Zircaloy-2 smooth-bore process tubes of the same outside diameter of existing aluminum tubes (HWS-5989), and the use of self-supported, aluminum-clad I\&E fuel elements.

2. Because of the expected long life of the Zircaloy-2 process tubes, the modification is considered permanent in that any future modifications which would require tube replacement will require very strong justification, because of the relatively high cost of Zircaloy-2 process tubes and the impact of tube replacement on reactor $11 f e$.

3. The criteria assume the completion of Projects CGI-883 and CGI-844, with reactor flow of $200,000 \mathrm{gpm}$ and power levels Iimited by bulk outlet temperature of $95^{\circ} \mathrm{C}$.

4. The modification will be in accord with the stated policy of General Electric Company with regard to reactor safety philosophy. (1) Thus, certain areas of technology may be included in the criteria for the purpose of recording the requirements, or requiring a review of the area for compliance with the criteria, or obtaining exceptions to the criteria for reasons other than safety and over which General Electric Company may not have control.

\subsection{Requirement}

The requirement defines a specific reactor condition which must be satisfied in order to meet the objectives of feasibility, operability, nuclear hazards and reactor life.

\subsection{Criterion}

The criterion defines the physical, chemical, or engineering limitations which must be imposed on a reactor component, process, or concept in order to satisfy the requirement, and is based upon the best available technical data or calculations. In certain areas where detailed technical data are

1) Trumble, R. E. Hazards Review - Power Level Limits for Hanford Reactors, $\mathrm{HW}-61580.8 / 17 / 59$. (Secret) 


\section{- DEELLSSFIFED}

lacking, the criterion may be arbitrary. Where such arbitrary limits may reflect on the safety, operability, and feasibility of the reactor, the limits should be biased by technical judgment, preliminary development studies, and reactor operating experience, rather than economic considerations alone. This criterion w1ll be modified from time to time as additional data become available.

\subsection{Data}

Where appropriate, data and approved methods of calculation are provided, as are references to additional data and supplemental calculational methods. These data and references will be supplemented as additional technical information becomes available.

In addition to the above, an Advice may be offered which, based on experience, may propose a method or concept which should be seriously considered in the reactor design.

\subsection{FUEL ELEMENT}

\subsection{Compatibility of Materials}

\subsubsection{Requirement}

The fuel cladding and self-support materials must be mutually compatible with the reactor materials at all polnts of contact or common ambient environment.

\section{1 .2 Criteria}

a. The fuel element cladding material and self-support material shall be X-8001 aluminum alloy or other similar aluminum alloy with equivalent or superior characteristics.

b. Support coatings (e.g. nickel plate) can be used, providing material compatibllity requirements noted above are met.

\subsection{Component Dimensional Compatibility}

\subsubsection{Requirement}

The installed process tube, the inlet and outlet nozzle assemblies, the associated fuel charging equipment, and the self-supported fuel element must be mutually compatible. The alignment and resultant clearances of the above components must be adequate to preclude damaging the fuel elements during the charge-discharge operation.

\subsubsection{Criterla}

a. The maximum fuel element length shall not exceed 12 inches, and the mintmum length shall be four inches. There shall be a minimum length 
difference of two inches between the nominal fuel lengths in the event that two or more types of fuel are used.

b. Nelther the specified maximum circumscribed support circle dimension nor the specifled minimum rail helght dimension shall be decreased by the charging operation more than a nominal .002 inch.

c. The fuel element self-support shall not be required to span any gaps greater than .250 lisch.

d. Physical strength of the clad fuel elements shall be sufficient to preclude development of physical distortion or deterioration of bond integrity as a result of axially applied charging forces up to 4000 pounds.

e. The self-supports will require a minimum of 800 pounds in direct compression loading to completely collapse the support. The discharge force required to damage fuel element supports during chargedischarge operation has not been defined yet. (The subject of' discharge forces and displacement discharge is discussed in a document to be issued by K. I. Hladek.)

\section{2 .3 Advice}

Approaches to restrictions or gaps between reactor components shall be relieved to minimize self-support rail damage during the transition through or across such areas under proposed charging veloclties and forces.

\subsection{Fuel Performance}

\subsubsection{Requirement}

The service life of the fuel element should be sufficiently long to permit continued reactor operation without significant reduction in operating efficlency due to fuel element fallure under the operating conditions selected to maximize economic gains; i.e., fuel performance shall not be limiting to exploitation of the reactor capabilities. The fuel element shall be designed to effect minimum damage to the process tube during fuel fallure or during discharge of a failed fuel element.

\subsubsection{Criteria}

a. Jacket corrosion during the service life of the fuel element shall be limited to a maximum corrosion rate of $10 \mathrm{mils} /$ month or a total aluminum loss of $20 \mathrm{mils}$, whichever is smaller.

b. The average exposure of aluminum-clad elements in any tube shall not exceed $1000 \mathrm{MWD} / \mathrm{T}$.

c. The maximum temperature of the uranium in any fuel element shall not exceed the alpha-beta transformation temperature, since such a service 
condition can lead to fuel distortion and cleavage failures. In practice, this temperature is held to about half of the maximum quoted.

d. The fuel elements shall have self-support structures attached to the exterior of the element, which shall have a minimum of .030 inch of collapsibility with increasing loads required for greater degrees of collapsibility.

\subsubsection{Advice}

Irradiation damage is expected to cause some fuel deterioration to some unknown degree, which will probably manifest itself in the form of fuel element warp, diameter growth, and fuel length changes. The combination of warp and diameter growth will result in the fuel binding in the process tubes and will necessarily require higher discharge forces than would be the case with rib-supported fuel.

Although it is not possible to design an optimum plutonium producing fuel geometry which will guarantee no tube damage, either during fuel fallure or during discharge after fallure, it is possible to minimize this type of damage by providing self-supports with a collapsibility feature. The self-support will be designed to require increasing loads to obtain increased deflection. Also, the weld between the self-support tab and fuel jacket surface will be the last point of fallure in the self-support under shear loading. Since these items and use of aluminum alloys fairly well define the behavior of a self-support, any variation in load-deflection characteristics can be obtained only from different conceptual designs.

\subsection{Fuel Enrichment}

\subsubsection{Requirement}

The reactor physics characteristics of the fuel must be compatible with the reactivity requirements and with the capabilities of the nuclear control and safety systems.

\section{4 .2 Criteria}

Two nominal fuel enrichments will be used: 1) natural uranium (0.71\% U235), and 2) enriched uranium (0.947\% U235).

\subsection{Hydraulic Characteristics}

\subsubsection{Requirement}

The hydraulic characteristics of the fuel element must be compatible with capabilities of the reactor coolant system. 


\subsubsection{Criteria}

\section{" DECLSSSFIFED \\ HW -74104}

a. The pressure drop across the fuel charge, plus any flow-mixing devices within the fuel train, shall not exceed that calculated by the equation

$$
\Delta p=0.157 F^{1.8} @ 20^{\circ} \mathrm{C}
$$

where $\Delta p=$ pressure drop across charge and $F=$ tube flow in gpm.

b. The design of the fuel element shall permit meeting the criteria for coolant boiling and heat transfer burnout under the limitations of the established reactor coolant system parameters.

\subsection{Fuel Element Description}

Fuel element shall be of the I\&E design concept, supported by collapsible self-supports attached to the cladding surface at a specified distance in from the ends of the fuel e.lements. Self-supports will be evenly spaced around the exterior of the fuel element near each end. Exact centering of the fuel element in the process tubes cannot be obtained as a result of tolerances on both the fuel elements and the reactor hardware; therefore, some degree of thermohydraulic unbalance will exist. In an effort to keep this unbalance to a minimum, the tolerances on all components will necessarily be very rigid. The following table gives the fuel dimensions and suggested tolerances: (2)

Canned Dimensions (Inches)

$$
\begin{array}{ll}
\text { a. O.D. } \\
\text { b. I.D. } \\
\text { c. Length }
\end{array}
$$

\section{Dimensions with Supports Attached}
a. Maximum support circle (full length of fuel)
b. Minimum support helght
c. Maximum projected support width
(full length of fuel - support misalignment angular or trans- lational)
d. Support width
e. Minimum bridge length
f. Collapsibility minimum

KVNS

$$
\begin{array}{r}
1.520 \pm 0.006 \\
0.420 \pm 0.006 \\
8.865+0.120 \\
-0.080
\end{array}
$$

KVES

$$
\begin{array}{r}
1.509 \pm 0.006 \\
0.432 \pm 0.006 \\
6.540+0.120 \\
-0.080
\end{array}
$$

\section{KVNS}

1.710

1.710

0.092

0.280

0.097

0.280
$0.187 \pm 0.004$
$0.187 \pm 0.004$
0.30
0.030
0.30
0.030

2) Heeb, C. M. Calculated Fuel Element Model Parameters KVNS and KVES, HW -73853 . $5 \longdiv { 2 9 / 6 2 }$. 


\subsection{PROCESS CHANNEL COOLING - HYDRAULIC CHARACTERISTICS OF PROCESS TUBE} CONNECTOR SYSTEMS

\subsection{Requirement}

The fuel element design of the modified reactor is based on certain maximum pressure drop characteristics of the front and rear connector systems. Increased pressure drop results in a lower flow rate or lower uranium inventory which reduces plant return. In addition to absorbing a minimum of the available pressure drop, the front connector system must be highly resistant to fallure. Rupture of a front connector can result in fuel element melting, despite an instantaneous scram, because the rear manifold pressure is insufficlent to drive steam from the tube and restore adequate cooling. Cavitation in the front connector system can impair the integrity of the system $s 0$ as to reduce the resistance to failure. It is therefore a requirement that cavitation in the front connector system be avoided during normal operation.

The outlet water temperature limits are determined to a large extent by the hydraulic characteristics of the rear fittings. The flow characteristics of the present fittings are such that any flow change or power surge which leads to flow instability would cause a high Panellit trip in time to prevent fuel jacket melting. An enlargement of these fittings would reduce this Panellit sensitivity and may also reduce allowable outlet water temperature limits. The rear fittings also cause some degree of pressurization in the flow stream upstream of the rear manifold. This suppresses boiling in the tube and also results in a single liquid phase of the coolant at the point of temperature measurement. The pressure drop in the rear connector system must therefore be sufficient to suppress active section boiling, to assure adequate transient pressure response under abnormal conditions, and to provide for adequate temperature monitoring.

\subsection{Criteria}

a. The pressure drop in the front connector system shall not exceed the value obtained from the following equation (coolant temperature of $20^{\circ} \mathrm{C}$ ):

$\Delta_{p}$ (front header - tube inlet) $=0.0156 \mathrm{~F}^{2}$, where $F$ is the tube flow rate in $\mathrm{gpm}$.

b. There wlll be no cavitation in the front connector system during normal operation.

c. The pressure drop in the rear connector system shall not be less than the value obtained from the following equation (coolant temperature of $\left.120^{\circ} \mathrm{C}\right)$ :

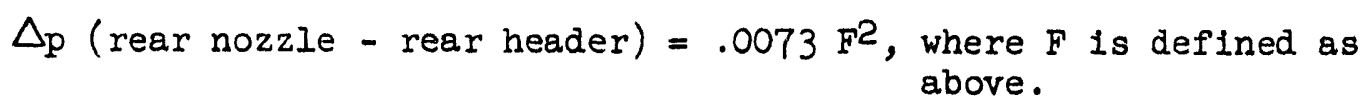


4.0 COOLANT BOILING AND HEAT TRANSFER BURNOUT

\subsection{Requirement}

To ensure system flow stablitity, adequate cooling of the fuel elements, the accurate measurement of tube exit water temperature, and to prevent adverse reactivity effects, the coolant supplied to the individual process tubes should be maintained in a single liquid phase. Therefore, coolant boiling within the individual process tubes should be avolded when operating at normal maximum design conditions of coolant temperature ( $95^{\circ} \mathrm{C}$ bulk water temperatures) and surface heat f'lux.

Partial or complete loss of normal coolant flow or a power level surge may result in overheating and melting of the fuel elements. It is, therefore, a requirement that continuous and adequate cooling be maintained at all times, and each process tube be protected against fuel element burnout by appropriate instrumentation.

\subsection{Criteria}

a. There shall be no bulk bolling (net steam quality) in any part of the process tube system during normal maximum operating conditions. Normal maximum operating conditions are those achieved during operation at $95^{\circ} \mathrm{C}$ bulk outlet water temperature. This criterion may be met by maintaining process tube exit water temperature below its saturation temperature. The boiling limit may be determined by the following equation: (3)

$$
T_{0}=\frac{T s-T i}{R}+T_{i}-\Delta t t-\Delta t p
$$

where To $=$ boiling limit, ${ }^{\circ} \mathrm{C}$.

$\mathrm{Ts}=$ saturation temperature at downstream end of active charge, ${ }^{\circ} \mathrm{C}$.

$\mathrm{T} 1$ = inlet temperature, ${ }^{\circ} \mathrm{C}$.

$\Delta t t=$ error limit of temperature measurement.

$\Delta t p=$ equivalent temperature error limit of tube outlet pressure measurement.

$R=$ factor to account for non-concentric placement of fuel elements in tube. $R=1.20$ for self-supported geometries.

b. There shall be no surface boiling (w1th no net steam generation) during operation at normal maximum design conditions. Surface boiling in present reactors occurs under conditions where the fuel elements are misaligned in the process tubes. Therefore, meeting this criterion is largely a matter of fuel design.

c. Conditions of inadequate cooling will be detected by individual tube pressure instrumentation, and a reactor scram initiated immediately.

3) Carlson, P. A. Basis for Establishing Minimum Support Height for KVN Fuel Elements, HW-74248. 7/11/62. (Secret) 
At the reduced tube power immediately following the reactor scram, adequate cooling flow will be available to prevent melting and gross damage even through a partially plugged process tube flow channel. These criteria can be met in the modifled reactor with the present Panelilt system in conjunction with presently specified instability Iimits.

\subsection{COOLANT SYSTEM MONITORING}

\subsection{Requirement}

The present requirements specified in Process Standards for monitoring reactor and tube power levels apply to the modified reactor. Individual process tube instrumentation will be capable of measuring accurately the coolant temperatures and flow rates. The flow monitoring devices will provide for an automatic reactor shutdown in the event of high or low flow signals. These are intended to protect against single-tube accidents which could cause reactor damage or contamination of the reactor environs. Examples of these events are undetected fuel element swelling, flow reduction from plugging of the process tube system by foreign materlals, rupture of a process tube or flttings, and unstable bolling of the coolant.

There will be no bulk boiling (net steam generation) in the process tube during normal operation. Operation with a single-phase coolant in the process tube will be monitored by approprlate outlet water temperature measuring devices.

During all periods of reactor operation, it will be necessary to monitor continuously the exit tube temperature of various zones of the reactor as an aid in controlling the reactor flux distribution.

\subsection{Criteria}

\section{Process Tube Flow Monitoring}

a. Each process tube shall be provided with a pressure sensing gage (Panellit gage) attached to the low pressure tap of a flow metering device (such as an orifice or venturi). The flow metering device will be sized to provide a pressure of $200-275 \mathrm{psig}$ at $67 \mathrm{gpm}$ and $425 \mathrm{psig}$ front crossheader pressure.

b. Each Panellit gage shall have a low and high pressure trip point connected electrically into the No. I Safety Circuit.

c. The reproducibility, accuracy, and response criteria shall correspond to that currently in use (HW-41000, Process Equipment Standard, Process Standard A-020). 


\subsection{Advice}

\section{Process Tube Temperature Monitoring}

a. Each process tube should be provided with an exit coolant temperature measuring device located in such a manner as to assure the temperature will be monitored at a point where excess pressure exists above saturation conditions.

b. To provide for possible future utilization of the temperature monitor in the Safety Circuit, it is necessary that the temperature detectors respond to 63 per cent of a step change in temperature within two seconds.

\subsection{CRITICAI EQUIPMENT}

\subsection{Requirement}

A failure of the process tube inlet nozzle, nozzle-to-tube joint, or connector could, by permitting fission products to be released into the reactor work area, result in an estimated two million dollar direct cost, plus four to six months of reactor downtime. Further, the Panellit system cannot assure protection against these failures; and elther partial or complete failure may be significant. Thus, the integrity of the nozzle assembly is the prime protection against heat transfer burnout, release of fission products to the reactor work areas, and the attendant clean-up cost that could result from such a fallure.

\subsection{Criteria*}

The minimum requirements that the nozzle assembly is expected to meet shall be based upon maximum credible service loads, and upon fatigue testing to three times the number of cycles (or repetitions of the load) that could reasonably be expected to occur during the service life of the nozzle. It is the intent of this criterion that the minimum requirements shall be sufficiently restrictive that fallure to meet these minimum requirements w1ll not necessarlly imply that the component w1ll fall in service.

To meet the requirement for maximum credible service loads, the inlet nozzle, nozzle closure, and tube-to-nozzle joint shall withstand, without perceptible damage, an internal pressure equal to five times the reactor maximum front crossheader pressure for a period of at least one minute. The inlet tube-to-nozzle joint shall withstand the tensile force that results from an internal pressure equal to five times the maximum front crossheader pressure.

* It Is the intent of these criteria to cover the nozzle itself, nozzle cap, connector and fittings, nozzle-to-gunbarrel joint, and the means of restraining the gunbarrel. 
The maximum credible tensile load shall be the maximum tensile load which the charging machine is able to exert. The nozzle shall withstand, without perceptible damage, the maximum charging machine force applied for a number of cycles equal to three times the number of cycles which could reasonably be expected to occur during the service life of the nozzle. This criterion shall similarly apply to the tube and front Van Stone flange.

The nozzle shall withstand, without perceptible damage, application of the maximum credible torque (from tightening and loosening end caps) for a number of cycles equal to three times the number of cycles which could reasonably be expected to occur during the service life of the nozzle.

Impact loading of nozzles may occur as a result of falling objects, such as fuel elements and tools commonly found on the charging work platform. The nozzle shall withstand without fallure or evidence of damage the maximum credible impact (fuel element falling a distance equivalent to the height of the reactor) a number of times equal to three times the number of impacts a single nozzle could reasonably be expected to surfer during its service life (16 drops for 20-year life, four drops for five-year life).

A most desirable criterion for the design of this critical assembly is that it be such that the fallure of any component of the assembly, as a result of environmental or service conditions, cannot result in a hazardous condition. Since this criterion cannot be met without impractical or impossible redundancy of components, the integrity of the assembly and its ability to withstand service conditions must be demonstrated.

\subsection{REACTOR OPERATIONAL CONTROL}

\subsection{Speed of Response}

\subsubsection{Requirement}

The horizontal control rods and/or any supplementary control devices must be able to respond at speeds such that their insertion and removal from the reactor can control. all concelvable normal reactivity transients. Greater speed may be available to minimize the required time for precritical control withdrawal (within nuclear safety limitations stated below).

\section{1 .2 Criteria}

a. The control rod speed shall be adequate to allow insertion of at least two mk of control capacity per minute.

b. It shall not be possible to withdraw the control system at a rate greater than $10 \mathrm{mk}$ per minute.

c. The precision required of the control system shall be such that the minimum, normally attainable adjustment of a single control element 
shall not result in a power level change greater than about .025 per cent of equilibrium power level.

d. Positive visual and audible alarms shall indicate when any control is being removed from the reactor.

\section{1 .3 Bases}

a. The fastest rate of reactivity increase which will be normally experlenced is that during a power level reduction. This is due to the cooling of the fuel with the attendant reactivity increase from the "prompt" temperature coefficient of reactivity. The control rod insertion rate must be adequate to shut the reactor down from equilibrium levels over a five-minute period. This will require the insertion of approximately $10 \mathrm{mk}$ of control capacity (to more than cover the prompt cooling effect), or about two mk per minute.

b. The permissible reactivity insertion rate from control withdrawal must be limited to that rate which would not result in a power excursion great enough to cause coolant bolling in the active zone before being terminated by a safety system trip. This permissible rate is governed by many things: the type of reactor safety instrumentation avallable, its time constants, its trip settings, and its geometrical coverage; the geometry and speed of response of the safety control system; the temperature coefficients; and the geometry and type of reactor loading. None of these parameters is permanently fixed. A value for the maximum permissible rate of control removal is thus specifled which will be compatible with present reactor safety instrumentation and a normal, partially enriched, uranium fuel loading in the zirconium-tubed $\mathrm{K}$ Reactors.

c. The ability to make small ( $\sim \mathcal{M}$ M) adjustments in reactor power level is essential to stable reactor operation. This ability is directly related to the prompt negative temperature coefficient of the reactor and the reactivity worth of the minimum increment of control movement. No theoretical bases are available for establishing a criterion for this subject; a criterion is, therefore, based on present $K$-Reactor experience. The $\mathrm{K}$ Reactors possess a prompt negative power coefficient of about $-.0015 \mathrm{mk} / \mathrm{MW}$. Observations have indicated that incremental control rod moresents of about 0.5 inch provide adequate reactor stability and control. On the average, a 0.5 -inch rod movement is worth about $.0015 \mathrm{mk}$; thus, on the average, a $0.5-1$ nch rod movement results in a power level change of $1 \mathrm{MW}$.

\subsection{Total Operational Control System Strength}

\subsubsection{Requirement}

The total operational control strength shall be sufficient to control

all the excess reactivity of the fission-product-free, fully loaded 
reactor over the entire range of operating exposures and temperatures.* The built-In control rod system need not itself fulfill this requirement; a supplementary control system may be utilized to provide a major portion of the total required strength, provided that the combined system continues to meet all requirements of control system speed and flexibility.

\subsubsection{Criteria}

a. The operational control system (Including supplementary control) must be capable of controlling the reactor under all normal conditions without relying on any portion of the reactor safety system.

b. Any supplementary control system provided shall be designed to enhance reactor operating efficiency by making its reactivity insertion and withdrawal rates as fast as possible, consistent with speed-ofresponse limitations. It shall be possible to insert supplementary control at a rapid enough rate to meet criterion (a) above at all times without adversely affecting reactor production efficlency.

\section{2 .3 Bases}

It is possible to operate the $K$ Reactors with a level of enrichment lower than that presently used, which would permit meeting requirements for operational control strength with the bullt-in horlzontal rod system alone. Such operation would drastically limit equilibrium power levels. Enricnment is provided for power flattening and maximum reactor production. The operational supplementary contro? system, which is provided to control the additional reactor excess reactivity so obtained, should be made as efficient as possible to prevent detracting from the production gains potentially attainable through the use of enrichment.

\section{2 .4 Advice}

The poison spline system presently used at the $\mathrm{K}$ Reactors for supplemental operational control represents the best supplemental control system presently avallable. Provisions should be made for use of the system in the zirconium-tubed $\mathrm{K}$ Reactors.

* NOTE: Under certain reactor startup conditions, the excess reactivity increases to a point just within the control capability of the normal control system. At this point, this system would not have the capability to overcome the net negative prompt coefficient and shut down the reactor rapidly. This condition is deemed acceptable, since any condition requiring a rapid shutdown at this time would be an abnormal condition, requiring safety system action. However, it is necessary to Impose procedural restrictions on VSR withdrawal after such a shutdown, to insure that the VSR system is not withdrawn while the excess reactivity still exceeds the capacity of the normal control system. 


\subsection{REACTOR SAFETY CONTROL}

\subsection{Total Control}

\subsubsection{Requirement}

For any accidental lattice reactivity increase, which would not normally fall under the control of the operational control device, there shall be sufficlent safety control capacity avallable to insure that no reactor reactivity state will develop following the accident which would signiflcantly increase the consequences of the accident.

\section{1 .2 Criterion}

The total strength of the safety control system (Ball $3 X$ system plus any in-place control elements) must be sufficient to prevent (under any accident conditions) delayed criticality, short of prompt critical, only to the extent that the consequences of the incident are not rendered more severe as a result.

\section{Interpretation}

The limiting case for total control in the $K$ Reactors is the loss-ofcoolant accident. The presently adopted and approved interpretation of the criterion is, therefore, for this accident. No reactivity state must develop in the reactor (after the scram and any excursion which may have accompanied the loss of coolant) which would decrease the probability of restoring cooling to the reactor. A delayed neutron critical state is not permitted until after a significant number of process tubes have been rendered useless as coolant channels by the melting of uranium. A prompt critical state is never permitted.

\subsubsection{Bases}

a. Calculations of the reactivity transient following an accident shall include consideration of fission-product decay, all temperature coefficlents at the exposure assumed, and any other effects, such as the effect of removal of coolant from the reactor.

b. Only poison material in place is.: to the accident, plus the Ball $3 X$ columns, shatl be constivis gurt of the safety control system. It cannot be assuned thi unvironnental conditions (temperature or nuclear radiation) or rucios. siuck integrity will permit the insertion of supplemenwily poisons after an accident.

c. It is assumed that a zirconium-tubed process channel is rendered useless once the melting point of uranium is reached. It is not clear, however, that poison materials which melt below the melting point of uranium will be retained in a zirconlum tube and continue to fulfill the supplementary total control function. It shall, therefore, be 
necessary that supplementary total control poisons charged into zirconium tubes possess melting points higher than the melting point of uranium. Lower melting point polsons may be utilized, provided it be demonstrated that they are retalned in the reactor unt1l the melting point of uranium is reached without a significant reduction in control strength.

The current zirconium retubing proposal is complicated by the fact that significant numbers of ribbed aluminum tubes w1Il be retained in the flat zone to permit poison spline insertion. Under water-loss accident conditions, these aluminum tubes will melt well before uranium melting occurs, thus rendering them useless as coolant channels. However, if the reactor cooling system is restored subsequent to such melting, but prior to uranium melting, it will be possible to prevent fission product release from fuel charged in zirconium process tubes, and thus significantly reduce the consequences of the disaster. It is therefore necessary to insure that poisons charged for total control remain effective until the melting point of uranium is reached, which would then render useless a majority of the process channels.

It is contemplated that aluminum- ${ }^{4} C$ poison splines will be charged into the ribbed aluminum tubes as supplementary total control poison. If this is to be permissible, it must first be conclusively demonstrated that these poisons will be retained in the reactor and remain effective, even after the aluminum process tube, fuel jacket, and the spline itself have melted. It is recommended that a testing and/or development program be initiated to:

1) Demonstrate the behavior of an aluminum- $\mathrm{B}^{4} \mathrm{C}$ spline charged into an aluminum process tube beneath an aluminum-jacketed fuel element as the temperature of the system is raised to the melting point of uranium.

2) If the test demonstrates that it is possible that the poison material will not be retained, development should begin on a poison material possessing a melting point higher than $1133 \mathrm{C}$.

d. After the melting of uranium has rendered useless a significant number of process channels, it is considered permissible for supplementary control polsons, and even control systems, to melt and even leave the reactor, as long as the rate of removal of such poisons from the reactor is slow enough to prevent the reactor from ever achieving prompt criticality. After the melting point of zirconium is reached, uranium redistribution in the reactor stack will render the reactor permanently subcritical. (4)

4) Nilson, R. Reactor Hazards Review, Zirconium Retubing at Hanford Reactors, HW $-63924.27 \overline{15 / 60 . ~(S e c r e t) ~}$ 


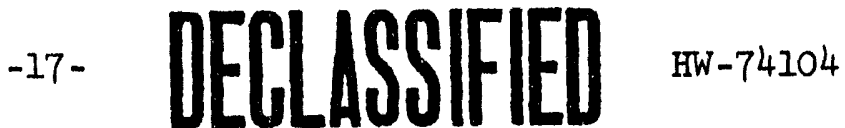

8.1 .4 Advice

It may be necessary to utilize the poison spline system for supplementary total control. Such requirements should be considered in establishing a pattern of tubes for poison spline insertion as outlined above.

\subsection{Speed of Control}

\subsubsection{Requirement}

The response time of the vertical safety rods nust be fast enough to satisfy the following speed-of-control criterion in the event of an accident from any credible cause.

\subsubsection{Criteria}

a. In the event of an accident, which in 1 tself will lead to reactor damage (such as permanent loss of coolant), the response of the vertical safety rods and associated trip circuits shall be fast enough such that any resulting power excursion will not significantly contribute to the reactor damage caused by the accident.

b. In the event of an accident, which would not in itself lead to reactor damage (such as inadvertent fast rod withdrawal), the response of the vertical safeiy rods and associated trip circuits shall be fast enough such that any resulting power excursion will not cause any damage more significant than fuel rupture.

\subsubsection{Bases}

a. Some reactor accidents, such as permanent loss of coolant, can ultimately lead to reactor destruction and release of fission products to the environs. No reactor control system could prevent such an occurrence. In such a case, the control system is merely required to limit any. reactor excursion accompanying the accident, so that the ultimate consequences, particularly the release of fission products, are not made more severe than those inescapably arising from the accident itself.

b. Certain accidents, such as inadvertent fast rod withdrawal during startup, obviously will not cause reactor damage in themselves. In such cases, any resulting excursion must be limited to prevent significant reactor damage.

\subsection{Fuel Element Design - Physics Aspects}

\subsubsection{Reactivity Parameters}

In general, it will be possible to meet all K-Reactor safety requirements utilizing any fuel design intended to maximize reactor production from an engineering standpoint. There are, however, desirable fuel design features which will tend to minimize the effect on production efficiency of meeting safety requirements. 
a. In the present aluminum-tubed $\mathrm{K}$ Reactor, power level is not restricted by the speed-of-control limit because of the relatively small reactivity increase when coolant is lost. Changing to thinner-wall zirconium tubes and increasing fuel diameters to provide the same pressure drops and flows should result in an even smaller reactivity change from loss of coolant. Any reductions in fuel size from the latter point should be examined to determine their effect on the relationship between reactor power level and the speed-of-control limit.

b. Changing from an aluminum-tubed to a zirconium-tubed reactor, with a corresponding increase in fuel dimensions as described in (a) above, w1ll have very little effect on the total control aspects of reactor safety. A reduction in fuel element size from the latter point would, however, result in an increase in the dry-reactor reactivity relative to wet-reactor reactivity, and might require the use of additional supplementary total control. Again, any reductions in fuel size should be examined for their effect on total control requirements.

c. Calculations indicate that the following fuel elements designed for a zirconium-tubed $K$ Reactor are acceptable in meeting speed-of-control and total control limits:

$\begin{array}{lcccccc} & \begin{array}{c}\text { Feed } \\ \text { Enrichment }\end{array} & \text { Can OD } & \begin{array}{c}\text { Uranium } \\ \text { OD }\end{array} & \begin{array}{c}\text { Uranium } \\ \text { ID }\end{array} & \text { Can ID } \\ \text { KVN } & .7115 \% & 1.520 & 1.431 & .533 & .420 \\ \text { KVE } & .947 \% & 1.509 & 1.420 & .545 & .432\end{array}$

8.4 Reactor Control During Outages and Startups

\subsubsection{Requirements}

All operational control and safety control requirements must be met at . all times during reactor outages and startups.

\subsubsection{Criteria}

a. During reactor shutdown, * the amount of inserted operational control (horizontal rods and/or approved supplementary controls) shall be sufficient to maintain the reactor subcritical without relying on any inserted vertical safety rods (exception - see NOTE on page 14). Fission product poisoning (xenon) may be considered in satisfying this requirement.

* Reactor shutdown is defined as a subcritical condition where the primary safety circuit is tripped and no control systems capable of automatic scram are avallable. (To meet total control requirements, the Ball $3 \mathrm{X}$ system may be unlocked and available for manual scram.) 
b. The vertical safety rods must be withdrawn and set in the automatic scram circuit before it will be possible to withdraw any horlzontal rods for reactor startup.

c. During reactor startup, the rate of withdrawal of both the operational control and the vertical safety rods shall be limited so as to provide a reactivity insertion rate no greater than $10 \mathrm{mk} /$ minute.

\section{Exception}

After a short outage, * when the excess reactivity is accurately known to be less than the capacity of Inserted operational controls, and when no more than two process channels have been charged with flosionable material during the outage, it is permissible to withdraw the vertical safety rods at the maximum physically attainable rate (all vertical rods out in six to ten minutes).

\subsubsection{Bases}

After an extended outage during which extensive process channel loading changes have occurred, xenon has bullt up and decayed, and the amount of supplementary polsons loaded has been altered, the prediction of the reactivity status of the reactor is subject to considerable uncertainty. It is assumed that this uncertainty could be as large as $5 \mathrm{mk}$, which could result in the excess reactivity exceeding the strength of the inserted operational control system during reactor startup. The rate of withdrawal of the vertical safety rod system during a reactor startup following such an outage must therefore be limited, so that if critical is inadvertently exceeded during vertical safety rod withdrawal, the resulting excursion will be terminated by automatic safety clrcult action before the equilibrium power level is exceeded in any process channel. It is also required during reactor startup that vertical safety rod witharawal be completed prior to withdrawal of the horizontal rods, in order to provide added assurance that critical will not be inadvertently attained during vertical safety rod withdrawal.

\subsection{FUEL HANDLING, SHIPPING, AND STORAGE}

\subsection{Requirement}

It is necessary that all uranium shipping, handling, and storage procedures be restricted so as to preclude the inadvertent attainment of a critical mass.

\subsection{Criteria}

a. The shipment, handling, and storage of unirradiated uranium shall be such that both an error or accident in the physical arrangement or mass of fuel and water inundation are required to achleve a critical mass.

* Defined as any outage where the xenon polsoning effect is increasing. 
b. The shlpment, handling, and storage of 1rradiated fuel (where shipment, handling, and storage under water are required for cooling and radiation protection) shall be such that a critical arrangement is prohibited by physical means in every situation possible, and by procedures in only those situations not subject to prevention by physical means.

\subsection{Bases}

a. In cases where control over configuration or shape is not possible, the allowed mass or volume of uranium wlll be no more than two-thirds of the minimum critical value for the mass or volume for the optimum shape (sphere).

b. In cases where control over configuration or shape is possible, the limits will be determined as in (a), except that the allowed mass or volume will be calculated for the actual shape or configuration.

It is not expected that the limits for the KV elements will differ from the limits for the KIV elements. However, further studies will have to be completed to verify this before actual limits can be specified.

10.0 SHIELDING AND CONTAMINATION CONTROL

\subsection{Requirement}

The radiation exposure which is received by Irradiation Processing Department personnel in the course of operating and maintaining the Hanford production reactors is sufficlently high that a great deal of administrative control is required to maintain those employees who routinely are exposed to radiation within the annual limit. Any revisions which are made to the reactors should not result in any increased exposure to personnel, but rather should result in reduced exposure, if this is practical.

\subsection{Criteria}

a. Revisions which are made to the rear reactor shield and rear face hardware shall not increase the general background level of $125 \mathrm{mr} / \mathrm{hour}$, which is currently experienced at about one foot from the tube caps during reactor shutdown. This is without benefit of rear-face-only decontamination, nor does it take into account the seasonal increase! in rear face dose rates experienced in the spring of the year. Rear face piping decontamination, using current methods, shall reduce rear face background dose rates to $30 \mathrm{mr} /$ hour IIf the revision provides for increase in the mean power level of the reactor, the above criteria shall still hold.

b. Revisions which are made to the front reactor shield shall not increase the general background level of $15 \mathrm{mrem} / \mathrm{hour}$ (gamma and neutrons) at one foot from tube caps over the central tube zone with the reactor at its full power capacity. 


\subsection{MODERATOF CONSIDERATIONS $(5)$}

\subsection{Requirement}

The safety of the reactor can be jeopardized by events
disrupting the continiuty of the moderator stack and which preclude operation of the safety and control systems. Further, there can occur some stack disruption, which would not jeopardize the safety of the reactor, but would result in increased difficulty in tube installations, even to the point of abandonment of channels. It is the objective of these criteria to set forth arbitrary standards of resistance to the damage from such events.

a. The removal of the aluminum process tubes shall not result in damage to the moderator which will impalr future tube installations or which would preclude meeting moderator integrity requirements (see $11.2(e)$ below).

b. The Insertion of the Zircaloy process tubes shall be accomplished without damage to the tubes. Damage to the tube is defined as scratches, galls, dents, flattening, or bending.

c. Maximum temperature of the moderator stack and reactor gas atmosphere following reconditioning shall not exceed that permitted by Process Stendards.

d. The self-supported fuel elements (of the present design or as modified by subsequent mockup testing) shall be readily charged over the expected life of the process tube without damage to the supports as a result of tube distortion. The distortion considers out-of-roundness of the tube as well as curvature. Damage to the supports is defined as flattening (greater than 2-3 mils), shearing, tearing, or severe galling.

e. Following whatever graphite channel conditioning may be required for ll.I(d) above, the integrity of the moderator stack shall be such that earthquakes or layer shifting shall not jeopardize the safety of the reactor.

\subsection{Criteria}

a. The radial stress applied to the tube and trunnion blocks shall not exceed 80 per cent of the ultimate tensile strength. Tensile strength of graphite at room tempereture is $1200 \mathrm{psi}$.

b. Maximum insertion force applied to Zircaloy-2 process tubes shall not be greater than 1500 pounds. Each tube shall pass an approprlate size plug (1.71," $1.0 .505^{\prime \prime}$ diameter) following insertion in the reactor.

5) Eenoliei, R. W. Extrapolation of the Vertical Displacement Contour of Top Center Process Tube Block Strings in the K Reactors, HW-74582. $7 / 31 / 62$. (Confidential) 
c. Standard methods of computation (using appropriate values of thermal conductivity for the lattice, contact resistance) shall be used to verify compliance with the moderator temperature requirement.

d. The reconditioning process shall be checked in a single channel mockup; and when the channel mockup containing a Zircaloy tube is distorted to the distortion which is expected to exist at the end of the desired tube life, a probe simulating a fuel element of current design shall just pass through the tube without sticking. (6)

e. The channel treatment shall be restricted to the tube and trunnion blocks, 1.e., not outside of these blocks, and the integrity of the stack shall be such as to meet the requirements of Section 2312 of the Uniform Builaing Code, 1955 Edition, for Zone 2 earthquake. $(7,8)$

\subsection{Advice}

It appears that the maximum reshaping will be required at the bend in the top center process tube channels between the fourth and fifth tube block from the inlet face. It also appears that the reshaping at this location will not requirs cutting more than about $1 / 2$ inch Into the concave side of the bend at the trunnion block, tapering to substantlally no cutting perhaps to the midpoints of the length of the two tube blocks. The angle between these tube blocks is now about 1.5 inches in 48 inches. At 1961 power levels, the angle between the longitudinal axes of these blocks will increase about 0.3 inch in 48 inches per year. Thus, in 20 years at 1961 power levels, the angle between the axes of the blocks will be 7.5 inches in 48 inches.

The experimental testing now being conducted will generate information on: 1) the curvature, and 2) the flattening of the zircaloy tubing as functions of: 1) the length and depth of cut in adjacent tube blocks, and 2) the angle between the blocks. Using dummy fuel element probes, limiting conditions of passage will be determined as functions of: 1) the length of the fuel element, 2) the length of the supports, 3) the location of the supports on the body of the element, and 4) the rotational position of the element supports relative to the plane of the tube bend.

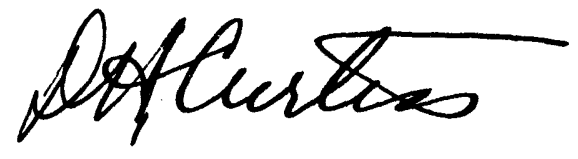

Edited by D. H. Curtiss Reactor Engineering Unit

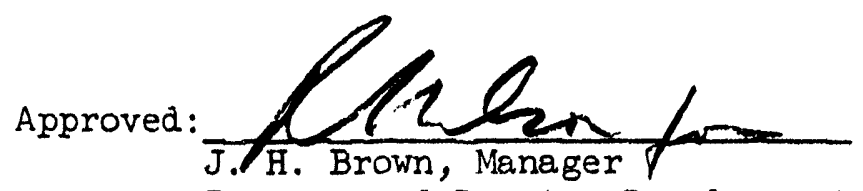
Research and Engineering

Process and Reactor Development Research and Engineering Section

DHC : vw

6) RusselI, A. Interim Report, 105-K Zirconium Process Tube Distortion Test, HW-74932. 9/12/62. (Secret)

7) Uniform Bullding Code, 1955 Edition, Pacific Coast Building Officials Conference.

8) Warren, C. Graphite Stability Under Earthquake Conditions, HW-27443. 3/19/53. 

